ORNL/LTR-2014/578

\title{
Economic Conditions and Factors Affecting New Nuclear Power Deployment
}

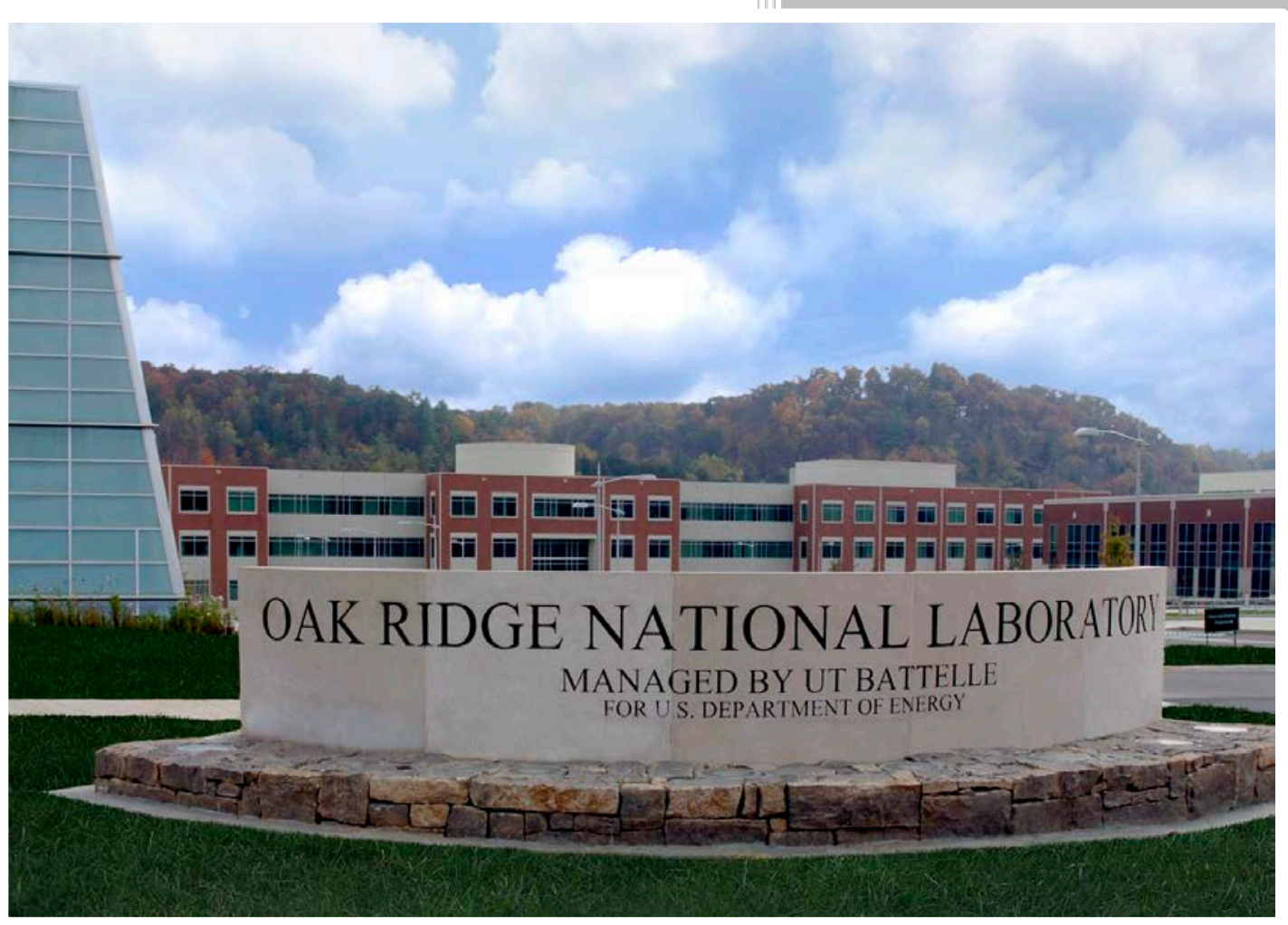

Approved for public release; distribution is unlimited.
T. Jay Harrison

October 2014 
This report was prepared as an account of work sponsored by an agency of the United States Government. Neither the United States Government nor any agency thereof, nor any of their employees, makes any warranty, express or implied, or assumes any legal liability or responsibility for the accuracy, completeness, or usefulness of any information, apparatus, product, or process disclosed, or represents that its use would not infringe privately owned rights. Reference herein to any specific commercial product, process, or service by trade name, trademark, manufacturer, or otherwise, does not necessarily constitute or imply its endorsement, recommendation, or favoring by the United States Government or any agency thereof. The views and opinions of authors expressed herein do not necessarily state or reflect those of the United States Government or any agency thereof. 


\title{
Reactor and Nuclear Systems Division
}

\section{ECONOMIC CONDITIONS AND FACTORS AFFECTING NEW NUCLEAR POWER DEPLOYMENT}

\author{
T. Jay Harrison
}

Date Published: October 2014

\author{
Prepared by \\ OAK RIDGE NATIONAL LABORATORY \\ Oak Ridge, Tennessee 37831-6283 \\ managed by \\ UT-BATTELLE, LLC \\ for the \\ US DEPARTMENT OF ENERGY \\ under contract DE-AC05-00OR22725
}





\section{CONTENTS}

Page

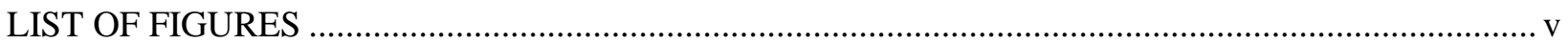

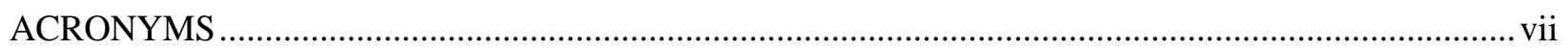

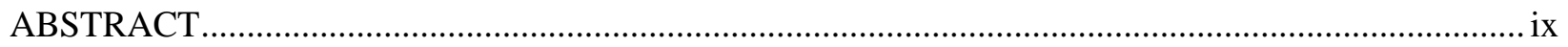

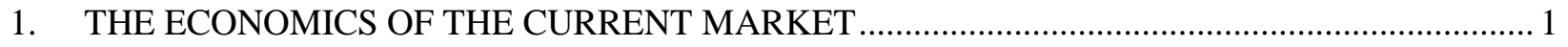

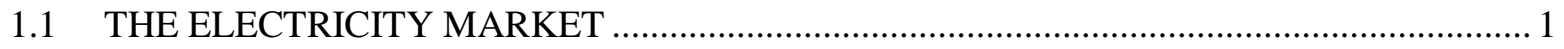

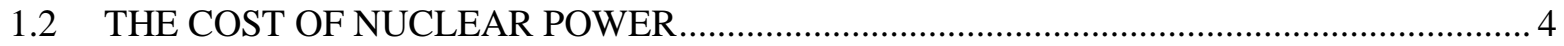

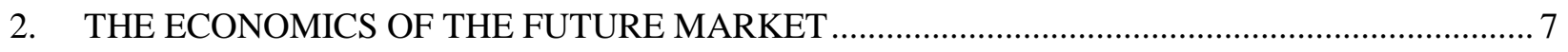

2.1 THE EFFECTS OF GAS AND RENEWABLES ............................................................... 7

2.2 THE EFFECTS OF MARKET SHIFTS (OR SUBSIDIES) ON NUCLEAR .......................... 11

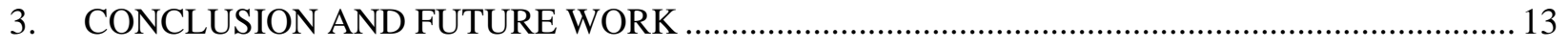

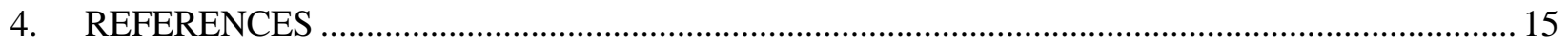





\section{LIST OF FIGURES}

Figure $\quad$ Page

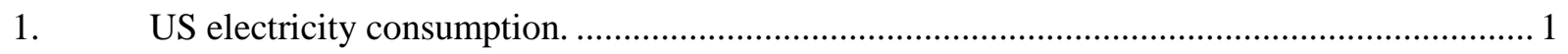

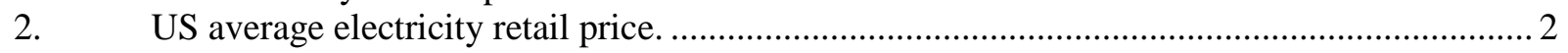

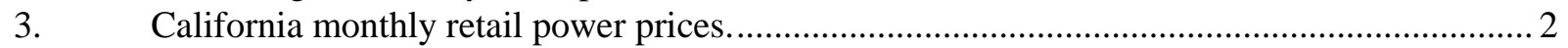

4. Daily wholesale power prices in California, April 2009-January 2013................................. 3

5. California average daily wholesale (spot) power prices at major trading locations,

January 1-June 2013. ..................................................................................................... 3

6. Capital recovery cost as a function of capital cost and interest rate........................................ 5

7. Total cost as a function of capital cost and interest rate........................................................ 6

8. Henry Hub natural gas spot prices..................................................................................... 7

9. Levelized costs for different power generators online in 2019......................................... 8

10. Levelized fuel and O\&M costs for different power generators............................................ 9

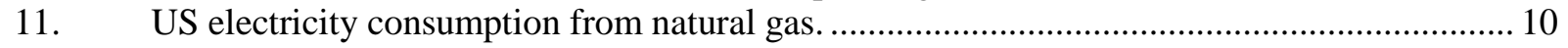

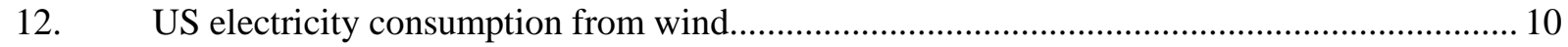

13. Subsidized cost as a function of capital cost and interest rate............................................. 11

14. Total subsidized cost with market shift............................................................................ 12 



\section{ACRONYMS}

D\&D

EIA

$\mathrm{kWh}$

$\mathrm{kWh}(\mathrm{e})$

MMBTU

MW(e)

NEI

NGCC

O\&M

ORNL

PV

TWh decontamination and decommissioning

Energy Information Administration

kilowatt (hour)

kilowatt hours electrical

one million British thermal units (MMBTU)

megawatts (electrical)

Nuclear Energy Institute

natural gas combined cycle

operation and maintenance

Oak Ridge National Laboratory

photovoltaic

terawatt hours 



\begin{abstract}
This report documents work performed in support of the US Department of Energy Office of Nuclear Energy's Advanced Small Modular Reactor (AdvSMR) program. The report presents information and results from economic analyses to describe current electricity market conditions and those key factors that may impact the deployment of AdvSMRs or any other new nuclear power plants. Thus, this report serves as a reference document for DOE as it moves forward with its plans to develop advanced reactors, including AdvSMRs. For the purpose of this analysis, information on electricity markets and nuclear power plant operating costs will be combined to examine the current state of the nuclear industry and the process required to successfully move forward with new nuclear power in general and AdvSMRs in particular.

The current electricity market is generally unfavorable to new nuclear construction, especially in deregulated markets with heavy competition from natural gas and subsidized renewables. The successful and profitable operation of a nuclear power plant (or any power plant) requires the rate at which the electricity is sold to be sufficiently greater than the cost to operate. The wholesale rates in most US markets have settled into values that provide profits for most operating nuclear power plants but are too low to support the added cost of capital recovery for new nuclear construction.

There is a strong geographic dependence on the wholesale rate, with some markets currently able to support new nuclear construction. However, there is also a strong geographic dependence on pronuclear public opinion; the areas where power prices are high tend to have unfavorable views on the construction of new nuclear power plants.

The use of government-backed incentives, such as subsidies, can help provide a margin to help justify construction projects that otherwise may not seem viable. Similarly, low interest rates for the project will also add a positive margin to the economic analysis. In both cases, the profitable price point is decreased, making more markets open to profitable entry.

Overall, the economic attractiveness of a nuclear power construction project is not only a function of its own costs, but a function of the market into which it is deployed. Many of the market characteristics are out of the control of the potential nuclear power plant operators. The decision-making process for the power industry in general is complicated by the short-term market volatility in both the wholesale electricity market and the commodity (natural gas) market. Decisions based on market conditions today may be rendered null and void in six months. With a multiple-year lead time, nuclear power plants are acutely vulnerable to market corrections.
\end{abstract}





\section{THE ECONOMICS OF THE CURRENT MARKET}

The first step in developing an analytical framework for advanced nuclear power economics is to understand the current nuclear power market. To that end, there are several components that directly impact the nuclear power market. The next sections of this report identify these factors: the electricity market, the cost of nuclear power, and the ways in which they influence the nuclear power market.

\subsection{THE ELECTRICITY MARKET}

From 2001-2007, US demand for electricity averaged a 1.8\% annual increase. However, following the downturn of 2007 the US demand for electricity averaged an annual 0.4\% decrease from 2007-2013. The US electricity consumption data provided by the Energy Information Administration (EIA) for the period 2000-2014 is shown in Fig. 1.

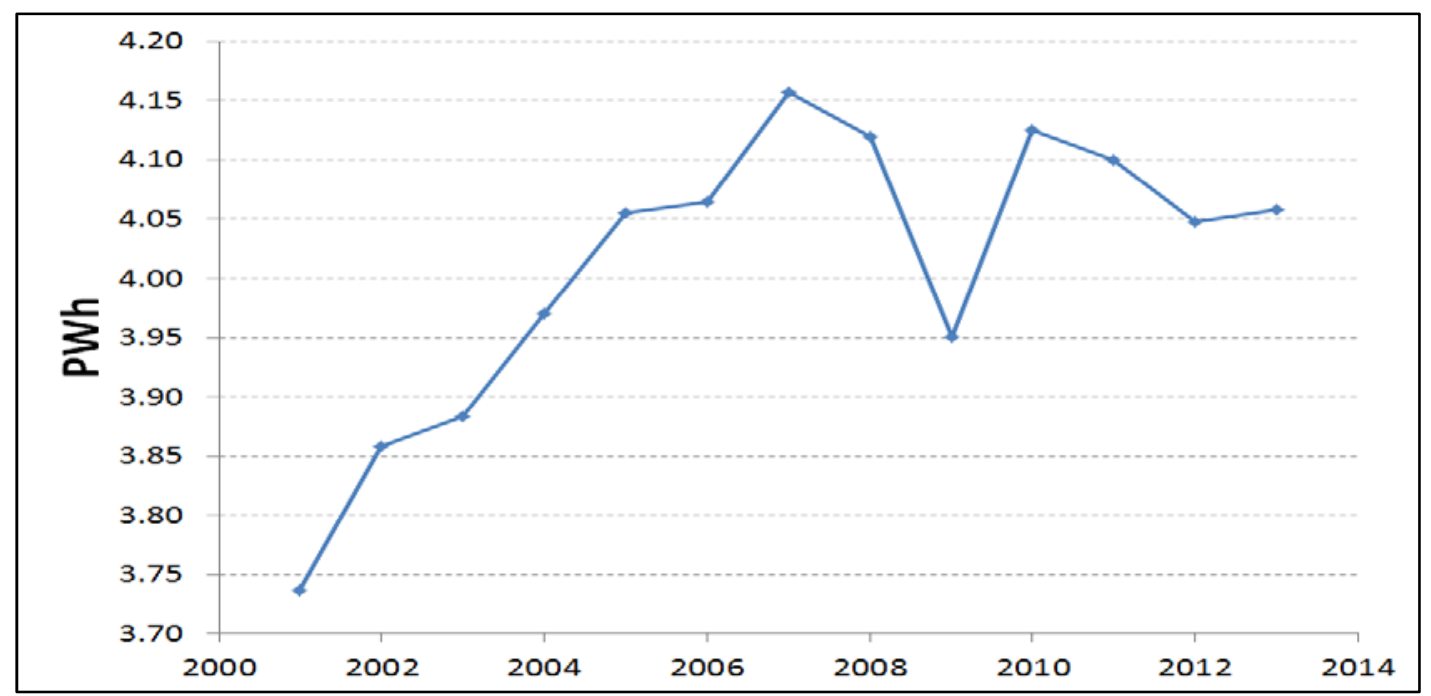

Fig. 1. US electricity consumption.

In absolute terms, US electricity demand in 2013 was equivalent to the electricity demand in 2006, which is $\sim 100$ TWh less than the 2007 peak. For reference, a single $1000 \mathrm{MW}(\mathrm{e})$ nuclear power plant with a $90 \%$ capacity factor produces $\sim 7.9$ TWh annually.

Along with the change in demand came a change in retail prices. Between 2001 and 2008, the electricity retail price in the US had an average annual increase of 4.2\%. From 2008-2013, that price curve flattened to an average $0.7 \%$ annual increase. The average electricity retail price in the US from 2001-2013 is shown in Fig. 2 (EIA). 


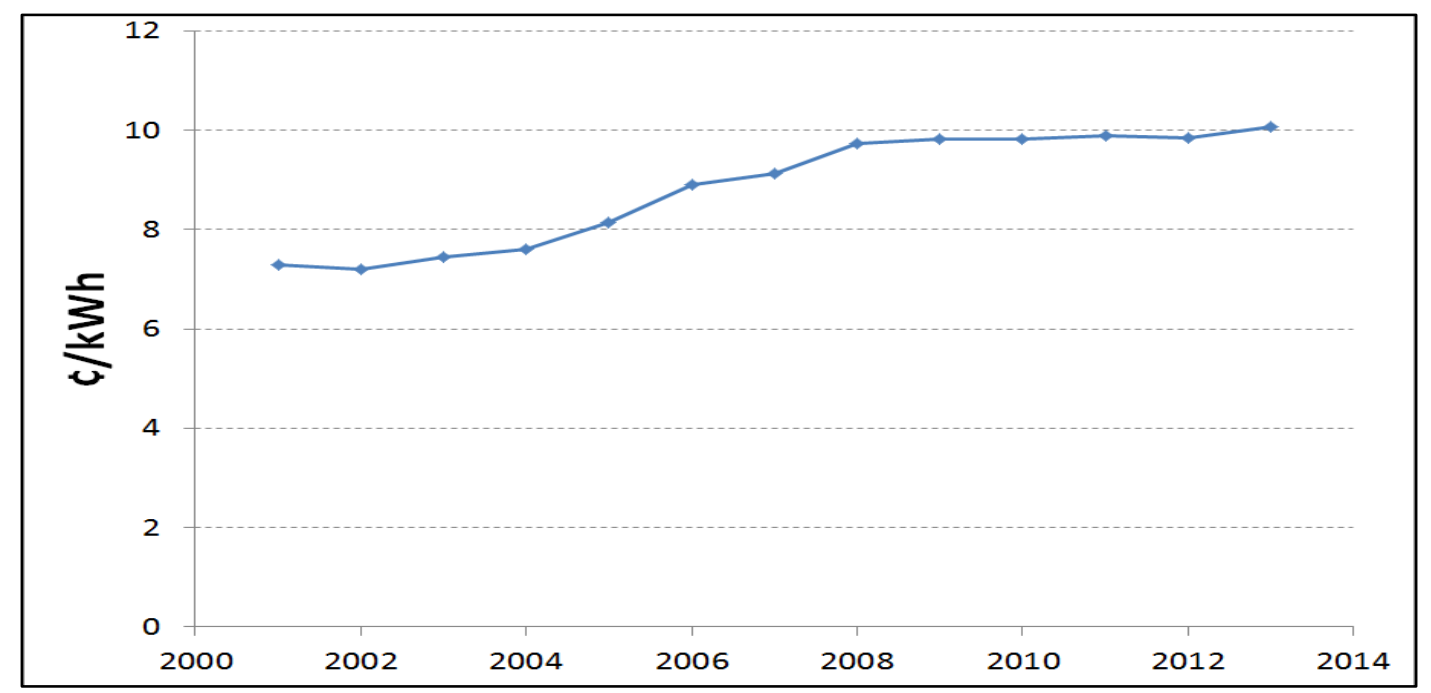

Fig. 2. US average electricity retail price.

It is important to acknowledge the difference between a retail price and a wholesale rate: ${ }^{1}$

- The retail price is the price the retailer (electricity distributor) charges when selling the product to the customer/end user.

- The wholesale rate is the price offered by electricity generators to purchasers of manufactured goods or to commercial sellers (electricity distributors).

From the perspective of a nuclear power plant, the wholesale rate is the value of importance since it will determine the economic feasibility of the enterprise.

As an example, Fig. 3 shows the retail price of electricity for the state of California [Ref. 1].

cents per kilowatthour

20

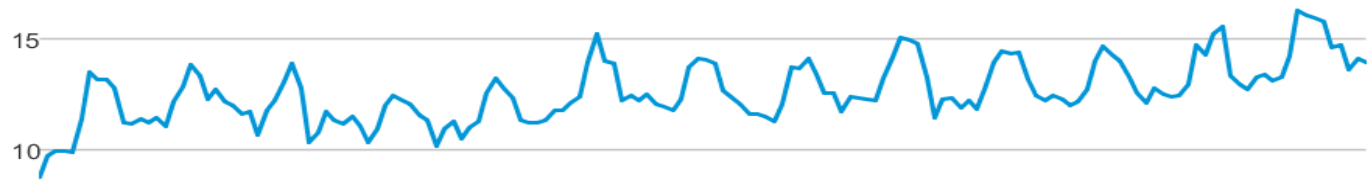

5

\begin{tabular}{|c|c|c|c|c|c|c|}
\hline \multirow[t]{2}{*}{2002} & \multirow[t]{2}{*}{2004} & 2006 & 2008 & \multirow[t]{2}{*}{2010} & \multirow[t]{2}{*}{2012} & \multirow[t]{2}{*}{2014} \\
\hline & & & all sec & & & \\
\hline
\end{tabular}

eia Source: U.S. Energy Information Administration

Fig. 3. California monthly retail power prices.

\footnotetext{
${ }^{1}$ In this document, "rate” and "price” will be used interchangeably. Both are given in terms of cost per unit of energy, such as
} $\$ /$ MWeh or $\$ / k W e h$. 
Figure 3 shows the average monthly retail price increasing from $\$ 0.10 / \mathrm{kWh}(\mathrm{e})$ or $\$ 100 /$ megawatt hours electrical (MWh[e]) — to more than \$0.15/kWh(e) —or \$150/MWh(e). Figure 4 shows California’s average wholesale price for comparison [Ref. 2].

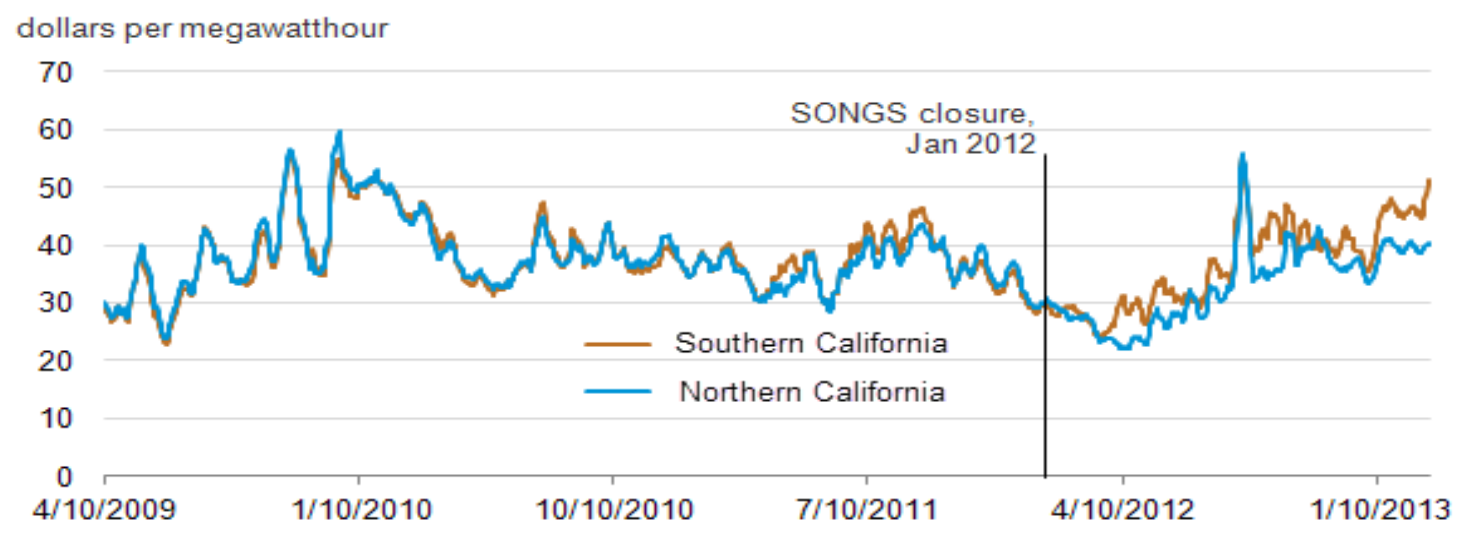

Fig. 4. Daily wholesale power prices in California, April 2009-January 2013.

Figure 4 shows that the wholesale range is on the order of $\$ 20-60 / \mathrm{MWh}(\mathrm{e})$. In comparison, the wholesale rate is substantially less than the retail rate in Figs. 3 and 4. Practically speaking, unless the nuclear power plant sells power directly to customers at the retail rate, or unless the nuclear power plant operator signs a power purchase agreement with a utility customer for a fixed higher rate, the best a nuclear power operator can hope for is the wholesale rate. Therefore, the wholesale rate sets the price point to determine the economic competitiveness of the nuclear power plant.

The wholesale rates in California shown in Fig. 5 are compared to those across the US [Ref. 3].

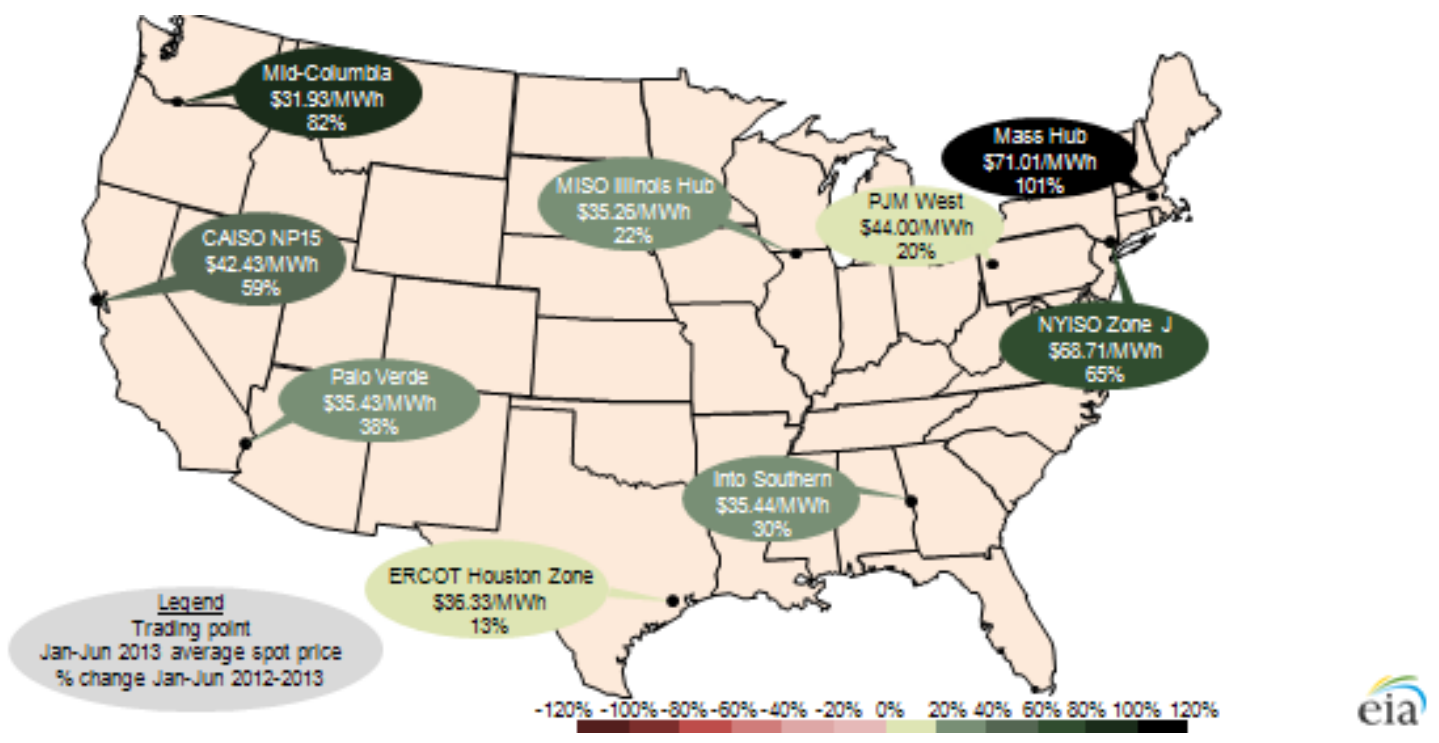

Fig. 5. California average daily wholesale (spot) power prices at major trading locations, January 1-June 2013. 
Fig. 5 shows the average wholesale price in the US in the first half of 2013, ranging from the low \$30s/MWh(e) in the Pacific Northwest (with large amounts of hydroelectric power) to the low $\$ 70$ s/MWh(e) in the Northeast. This provides a range of potential wholesale prices against which to gauge the economic performance of nuclear power.

\subsection{THE COST OF NUCLEAR POWER}

The economic performance of nuclear power depends on a nuclear power operator's ability to make a profit by selling the electricity generated by the nuclear power plant. This profit is the difference between the wholesale rate (or the agreed-to power purchase rate) and the cost to operate the nuclear power plant. The wholesale rate is estimated in the previous section, and this section estimates the cost to operate the nuclear power plant.

The operating cost of the nuclear power plant is typically divided into several categories and reported in cost per energy unit, such as $\$ / M W h(e)$. These cost categories are:

- capital recovery - the cost of plant construction;

- non-fuel operation and maintenance (O\&M) — the cost of day-to-day operations;

- fuel - the cost of purchasing, handling, using, and disposing of nuclear fuel; and

- decontamination and decommissioning (D\&D) — the cost of returning the nuclear power plant site to greenfield status.

For existing (already-built) nuclear power plants, O\&M, fuel, and D\&D costs are tracked and reported by the Nuclear Energy Institute (NEI) [Ref. 4]. In 2013, the average fuel cost at a nuclear power plant was $\$ 7.9 / \mathrm{MWh}(\mathrm{e})$, and the average O\&M cost was $\$ 15.1 / \mathrm{MWh}(\mathrm{e})$. Fuel disposition costs are accrued through the Nuclear Waste Fund fee of \$1/MWh(e) (currently suspended [Ref. 5]).

The estimated D\&D cost per reactor is $\$ 300-500 \mathrm{M}$. Assuming $\$ 500 \mathrm{M}$ for a 1000 MWe reactor operating over 40 years with a $90 \%$ capacity factor, this is approximately $\$ 1.6 / \mathrm{MWeh}^{2}{ }^{2}$ This provides a total sum of \$25.6/MWh(e) when including the Nuclear Waste Fund fee.

The EIA also provides estimates for nuclear power costs (as well as other sources) [Ref. 6]. The EIA reports \$23.6/MWh(e) for O\&M and fuel; this is in line with the NEI estimate of \$23/MWh(e). The EIA also includes estimates for transmission investments at $\$ 1.1 / \mathrm{MWh}(\mathrm{e})$; this is essentially negligible.

Comparing this to the typical wholesale rate of $\$ 30+/ \mathrm{MWh}(\mathrm{e})$, a nuclear operator can make a profit selling power to the wholesale market. However, this cost of electricity does not include the capital recovery cost.

The EIA estimates the levelized capital cost, which is the capital recovery cost, at $\$ 71.4 / \mathrm{MWh}(\mathrm{e})$ for new nuclear construction. With an assumed capital cost of around $\$ 5500 / \mathrm{kWe}$ [Ref. 7], a 40 year lifetime, and a $90 \%$ capacity factor, the assumed annual interest rate can be found. The formula to calculate a periodic payment $P$ given a total amount amortized $A$ over $n$ periods at periodic interest rate $r$ is:

$$
P=A r \frac{(1+r)^{n}}{(1+r)^{n}-1}
$$

The total capital $A$ for a $1000 \mathrm{MW}(\mathrm{e})$ plant is $\$ 5.5 \mathrm{~B}$, and the assumed $n$ is 40 years. For a 1000/MW(e) plant at $90 \%$ capacity factor, the annual power generation is $7.884 \times 10^{6} \mathrm{MWh}(\mathrm{e})$. Thus, the per-MWh(e) capital recovery payment $c$ is given by:

\footnotetext{
${ }^{2}$ This assumes no accrual of interest in the D\&D escrow account.
} 


$$
c=\frac{5.5 \times 10^{9}}{7.884 \times 10^{6}} \frac{r(1+r)^{40}}{(1+r)^{40}-1}=697.62 \frac{r(1+r)^{40}}{(1+r)^{40}-1}=71.4 \rightarrow \frac{r(1+r)^{40}}{(1+r)^{40}-1}=0.1023
$$

Solving numerically, this leads to an assumed annual interest rate $r$ of $\sim 10 \%$. Reducing the interest rate ${ }^{3}$ to $5 \%$ reduces the capital recovery cost to $\$ 41 / \mathrm{MWh}(\mathrm{e})$, but this is by itself more than the typical wholesale rate in most parts of the country. Similarly, reducing the interest rate to $5 \%$ and extending the lifetime to 60 years reduces the cost to $\$ 37 / \mathrm{MWh}(\mathrm{e})$, also by itself more than the wholesale rate.

The Summer and Vogtle construction projects, each rated at 2234 MW(e) total, currently cost $\$ 4900 / \mathrm{kW}(\mathrm{e})$ [Ref. 8] and $\$ 6300 / \mathrm{kW}(\mathrm{e})$ [Ref. 9], respectively. Thus, the $\$ 5500 / \mathrm{kW}(\mathrm{e})$ falls in that range, making it a valid assumption for cost estimation.

Assuming a $0 \%$ interest rate (as for a construction project fully financed by federal funds or existing private capital) and a 40 year lifetime and $90 \%$ capacity factor, the capital recovery cost is $\$ 17.5 / \mathrm{MWh}(\mathrm{e})$. When added to the O\&M, fuel, and D\&D costs, this brings the total nuclear cost to the upper \$30s MWh(e).

Figure 6 shows the capital recovery as a function of capital cost in $\$ / \mathrm{kW}(\mathrm{e})$ and a function of annual interest rate.

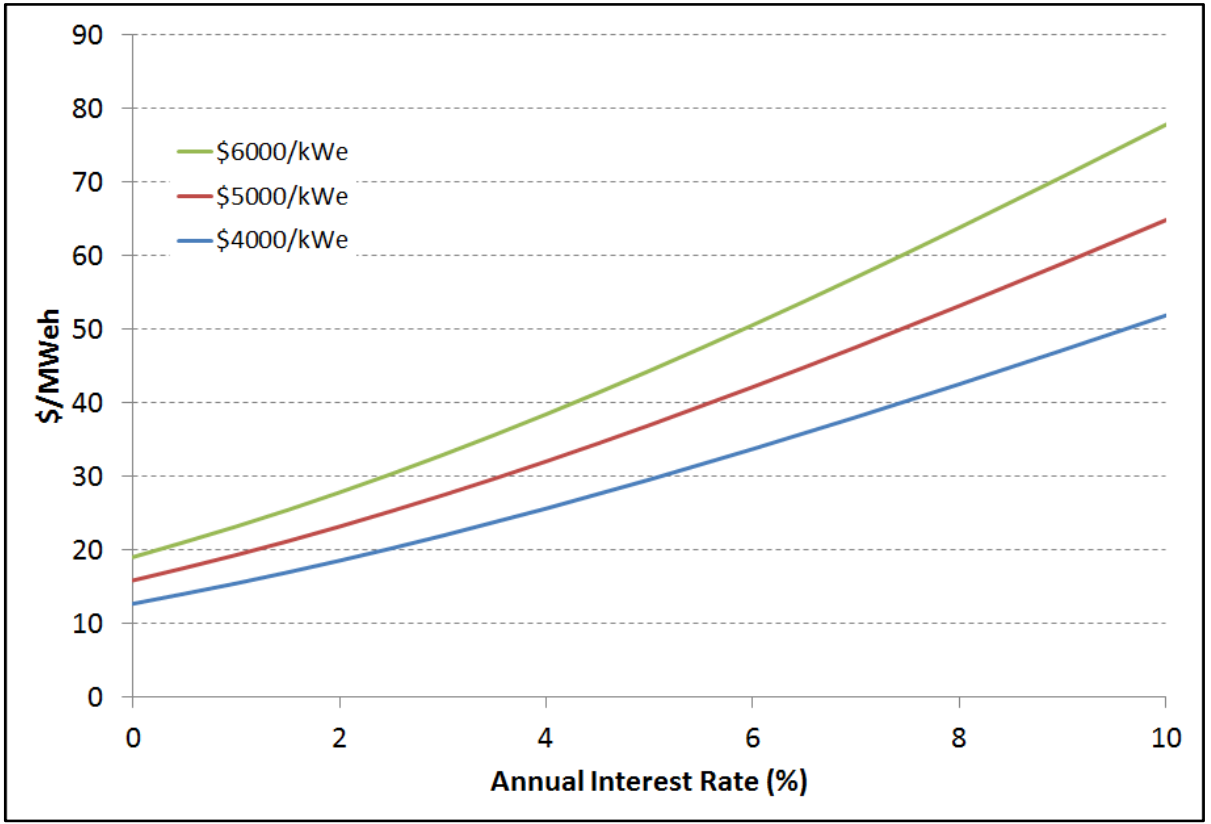

Fig. 6. Capital recovery cost as a function of capital cost and interest rate.

\footnotetext{
${ }^{3}$ This does not imply that $5 \%$ is the "correct” rate. This merely demonstrates that a lower interest rate does not necessarily make the capital recovery cost more palatable.
} 
Assuming an O\&M, fuel, and D\&D cost of $\sim$ 26/MWh(e), Figure 7 shows the total cost.

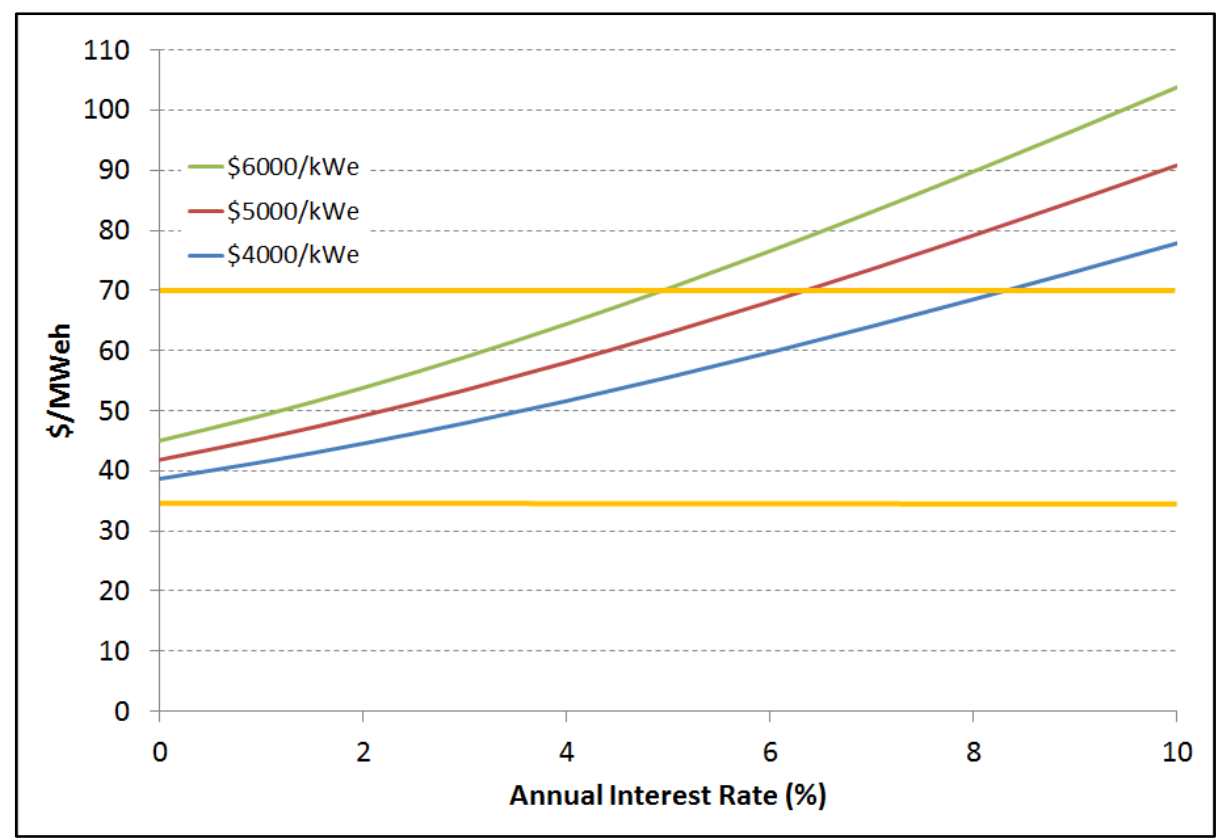

Fig. 7. Total cost as a function of capital cost and interest rate.

The gold lines at $\$ 35 / \mathrm{MWh}(\mathrm{e})$ and $\$ 70 / \mathrm{MWh}(\mathrm{e})$ mark the approximate range of wholesale rates as shown in Fig. 5. Even at the low end of the potential range of capital costs $(\$ 4000-6000 \mathrm{~kW})$, the total cost of nuclear electricity is always greater than the lower end of wholesale prices. However, nuclear electricity remains competitive at $\$ 4000 \mathrm{~kW}$ at the upper end of wholesale prices through $8 \%$ annual interest rate.

As Fig. 5 shows, the economic competitiveness of a nuclear power plant can be seen as a function of the market wholesale rates and the interest charged on the capital costs. In the current market, this limits the economic competitiveness to the northeastern states, and area that is not currently receptive to new nuclear construction.

In effect, construction and operation of a nuclear plant in a regulated market avoids potential volatility in the wholesale price market, such as that shown in Fig. 4. For reference, the Summer and Vogtle construction projects are located in regulated markets, which removes some of the competitive aspects of gas and renewables (see Sect. 2.1). Therefore, market pressures on their economic viabilities are not as significant as they would be in other geographic areas. Also, the Watts Bar Nuclear Plant now in completion is located in a regulated market. 


\section{THE ECONOMICS OF THE FUTURE MARKET}

Based on NEI data, the economic competitiveness of nuclear power is currently still favorable for most operating nuclear power plants. While some plants cannot compete successfully based on their respective markets, such as Kewaunee [Ref. 10], most continue to make profits for their operators. However, because these plants have limited operating lives, nuclear construction will be pursued, taking into consideration the most favorable market timing and processes for development and implementation.

\subsection{THE EFFECTS OF GAS AND RENEWABLES}

The price of gas has dropped to an all-time low in 2014. Figure 8 shows the Henry Hub natural gas prices from 1998-2014 [Ref. 11].

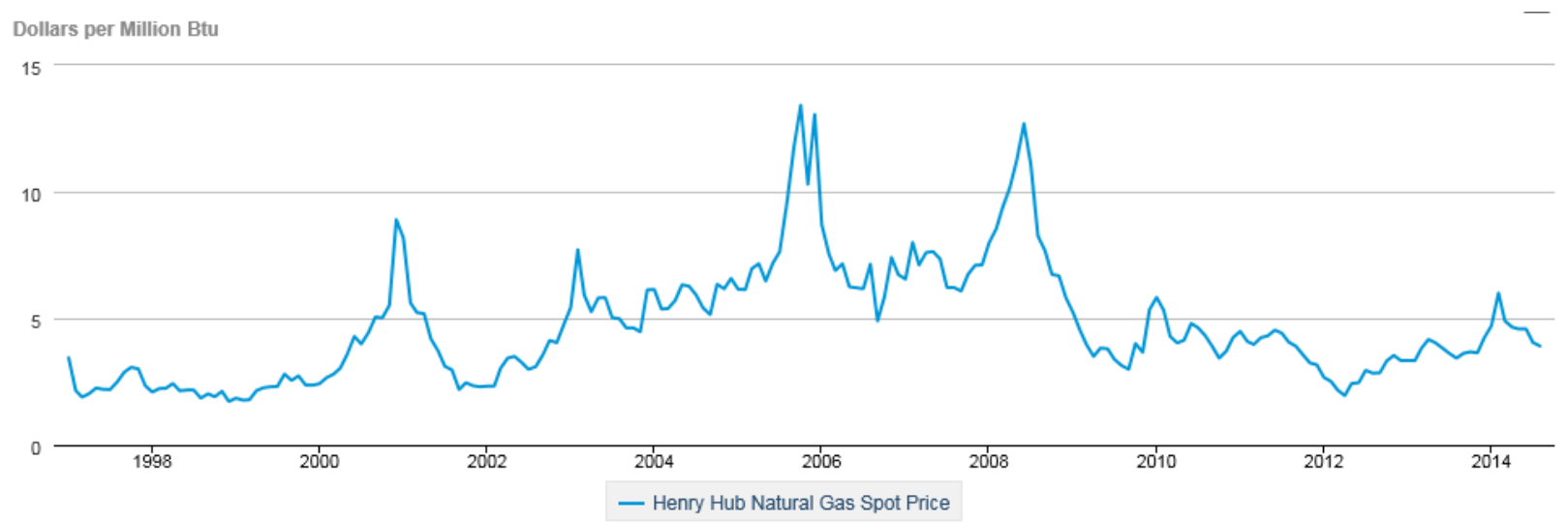

eia Source: U.S. Energy Information Administration

Fig. 8. Henry Hub natural gas spot prices.

The natural gas prices peaked at around \$14/ million British thermal units (MMBTU) in 2005-2006 and again in 2008-2009, but since then have generally been less than \$5/MMBTU. This is an obvious driver in the power industry since natural gas power plants have lower capital costs. Historically, natural gas power plants have had higher fuel prices to balance their capital cost advantage, but that is no longer the case. 
Figure 9 shows the levelized costs for different power sources [Ref. 6].

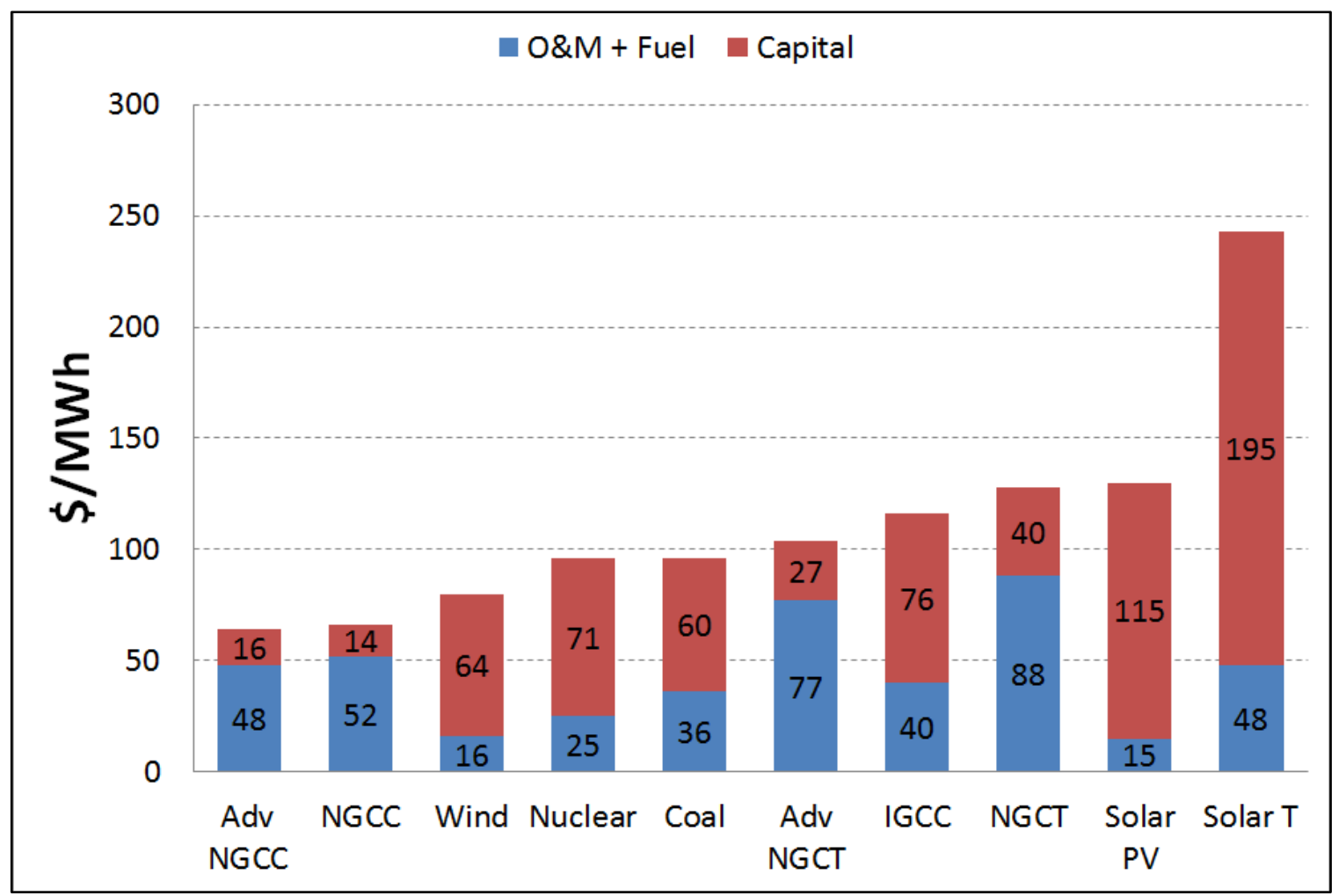

Fig. 9. Levelized costs for different power generators online in 2019.

Nuclear power appears in Fig. 9 with the previously discussed \$71/MWeh capital recovery and the \$25/MWh(e) O\&M and fuel cost. Natural gas combined cycle (NGCC) generation has a total cost of $\$ 66 / \mathrm{MWh}(\mathrm{e})$, but it only has a $\$ 14 / \mathrm{MWh}(\mathrm{e})$ capital recovery cost. This implies that as gas prices go down and stay low, the O\&M and fuel cost—estimated at \$52/MWh(e)—will also go down and stay low.

Gas power generation also enjoys a relatively simple regulatory approval process, a short construction period, and generally broad support in the deployment of the power plants themselves. This does not take into consideration the issue of support for the extraction of natural gas. Overall, from a utility's perspective, it is a lower-risk investment to build a gas power plant and take advantage of low gas prices. This is especially evident from looking back at Fig. 8. Gas prices are not at unprecedented lows: they were previously at this level in the late 1990s. However, from a capital cost perspective, it is less risky to build a $<\$ 1000 / \mathrm{kWe}$ gas plant over 2 or 3 years than a $\$ 5500 / \mathrm{kWe}$ nuclear plant over 6 years [Ref. 7]. 
Figure 10 shows the same generation sources without the capital cost.

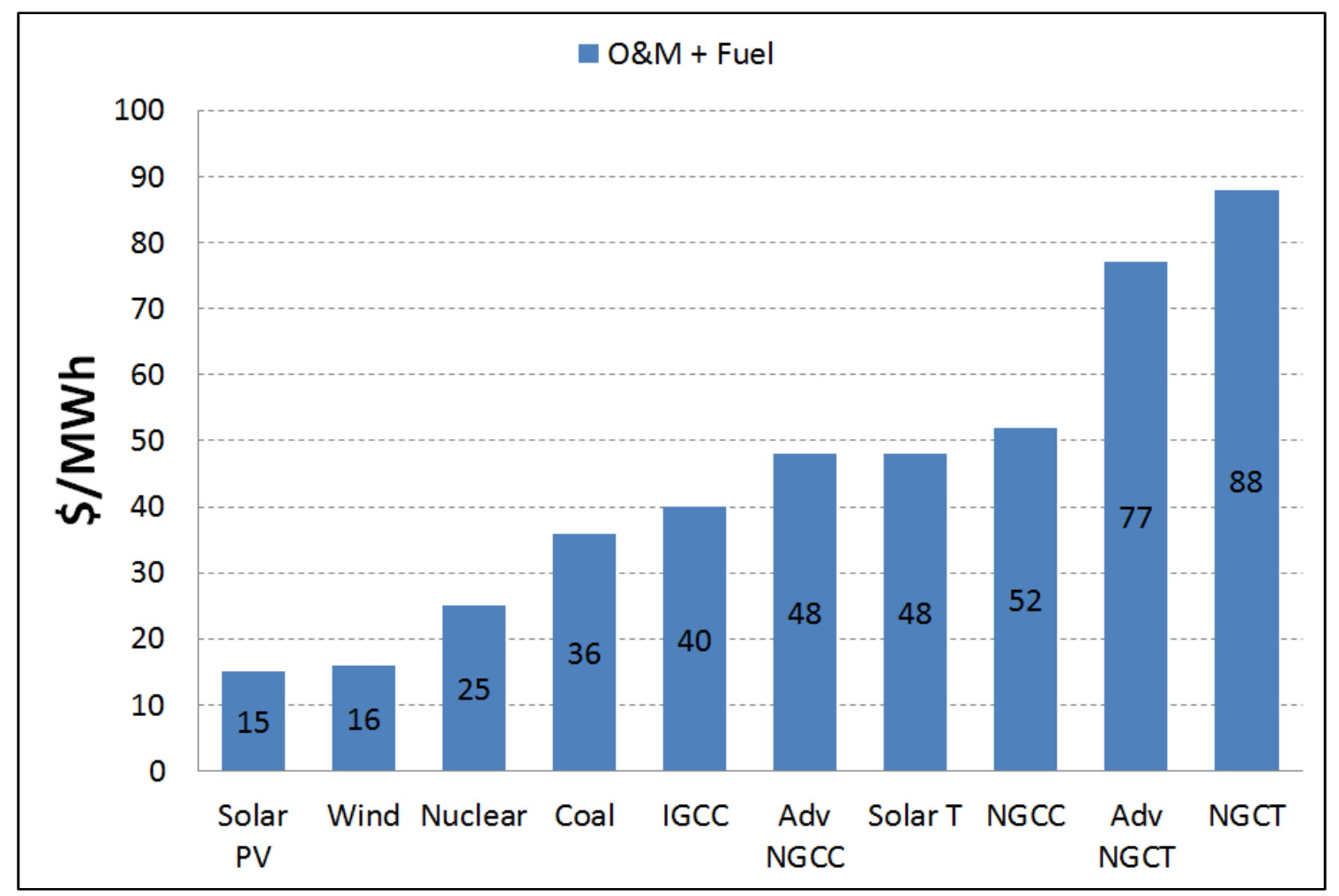

Fig. 10. Levelized fuel and O\&M costs for different power generators.

When re-sorted by O\&M and fuel cost, the long-term costs for solar photovoltaic (PV) and wind are less than all other power generation sources, with nuclear and coal close behind. This implies that even when taking into account the relatively large capital recovery costs associated with both wind and solar photovoltaic, the long-term benefits are perceived as worthwhile. This also does not take into consideration any subsidy provided for the construction of renewable projects.

Thus, it is clear that both gas and renewables are the most attractive options for new power generation. Figure 11 shows recent trends for gas, and Fig. 12 shows recent trends for wind. The data are taken from EIA. 


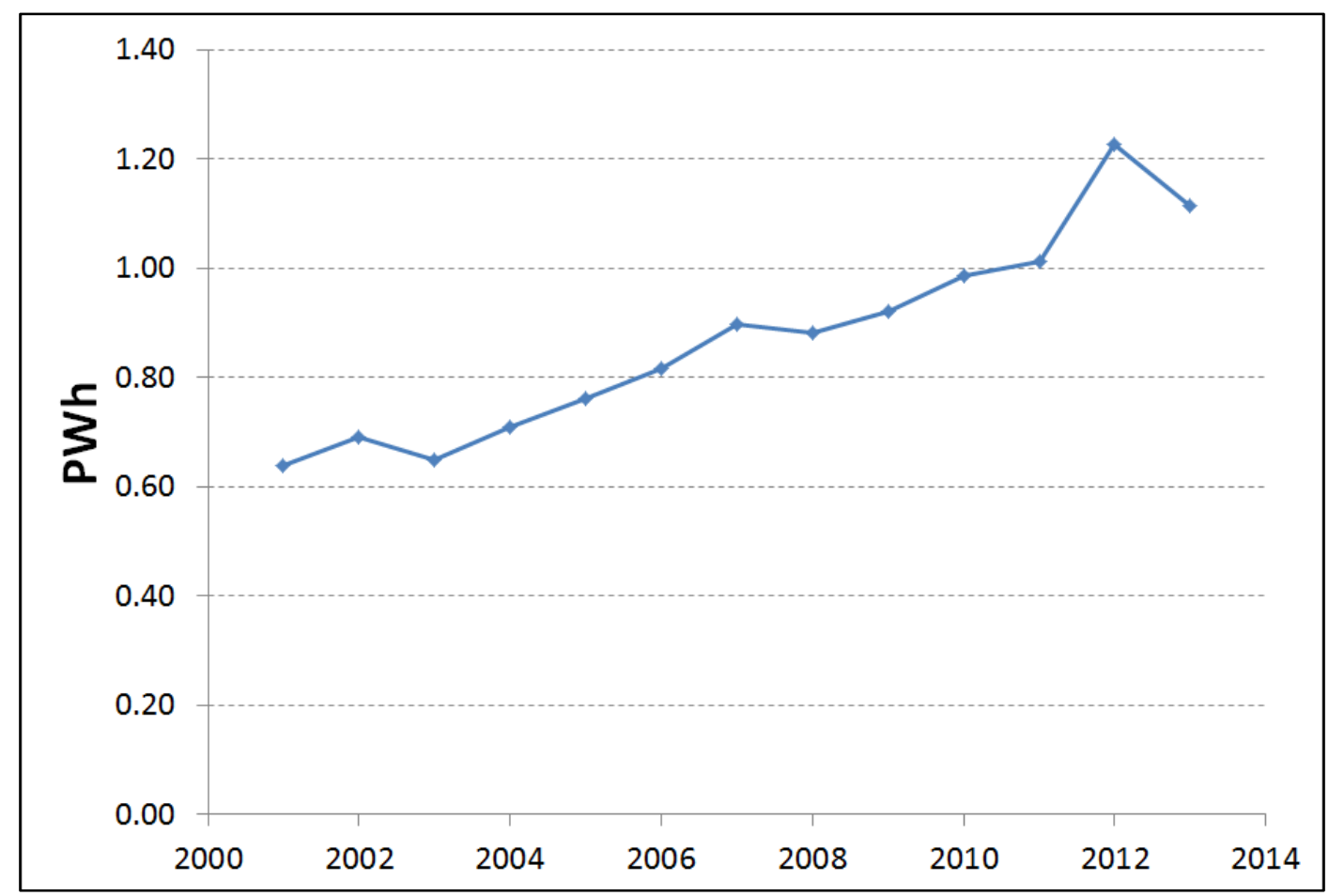

Fig. 11. US electricity consumption from natural gas.

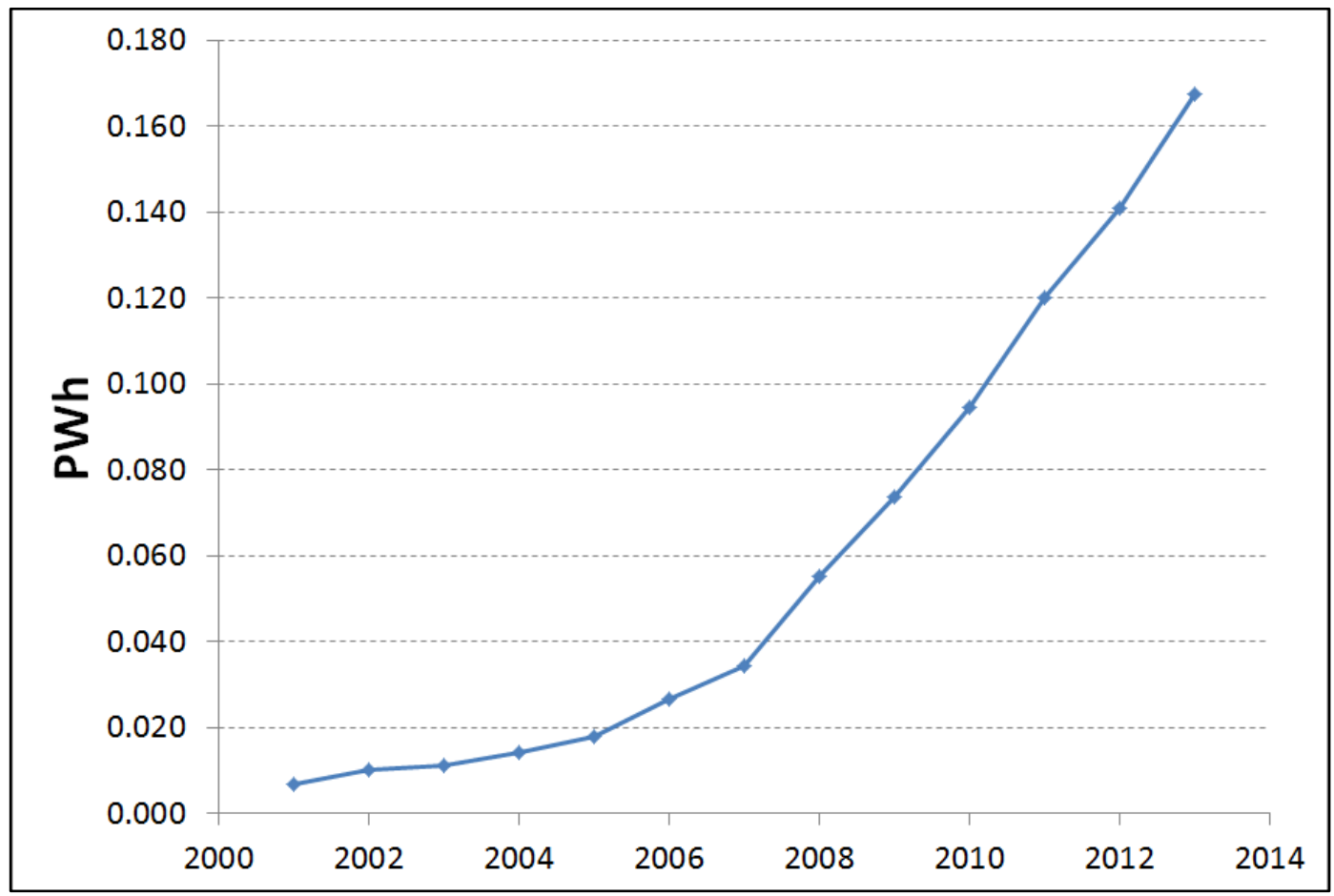

Fig. 12. US electricity consumption from wind.

Both figures show a steady increase in the electricity consumption from wind and natural gas. Clearly, wind and natural gas are having substantial growth, and there is little reason to suspect they will not continue to sustain growth into the immediate future. 


\subsection{THE EFFECTS OF MARKET SHIFTS (OR SUBSIDIES) ON NUCLEAR}

As shown in Fig. 7, a shift in the wholesale market or an additional subsidy for nuclear production would make nuclear power more economically attractive. Energy production in general has historically been government subsidized [Ref. 11]. The data that the EIA collects, in fact, assume an $\$ 18 / \mathrm{MWh}(\mathrm{e})$ production tax credit for advanced nuclear [Ref. 6].

Figure 13 is an adaptation of Fig. 7 to include the $\$ 18 / \mathrm{MWh}(\mathrm{e})$ credit.

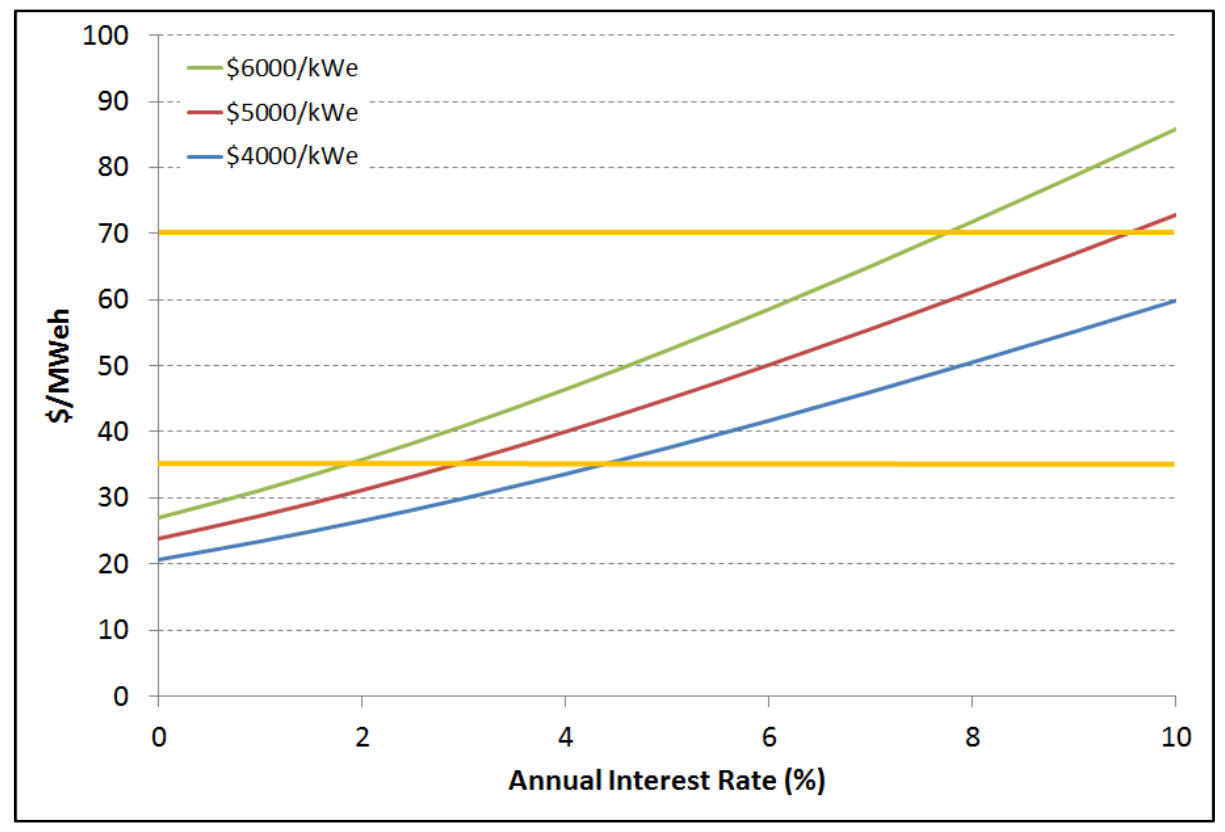

Fig. 13. Subsidized cost as a function of capital cost and interest rate.

Including the subsidy makes nuclear power cost viable for low interest rates. Figure 14 includes the subsidy, as well as a $\$ 15 / \mathrm{MWh}(\mathrm{e})$ upward shift in the wholesale rate; this is a feasible change in the market, as shown in Fig. 4, from April 12, 2012, to January 10, 2013.

Combining a market shift of $\$ 15 / \mathrm{MWh}(\mathrm{e})$ with an $\$ 18 / \mathrm{MWh}(\mathrm{e})$ subsidy makes nuclear power an economically viable option for low interest rates for the full range of anticipated construction costs, and for low construction costs, nuclear power is viable even for midrange interest rates. 


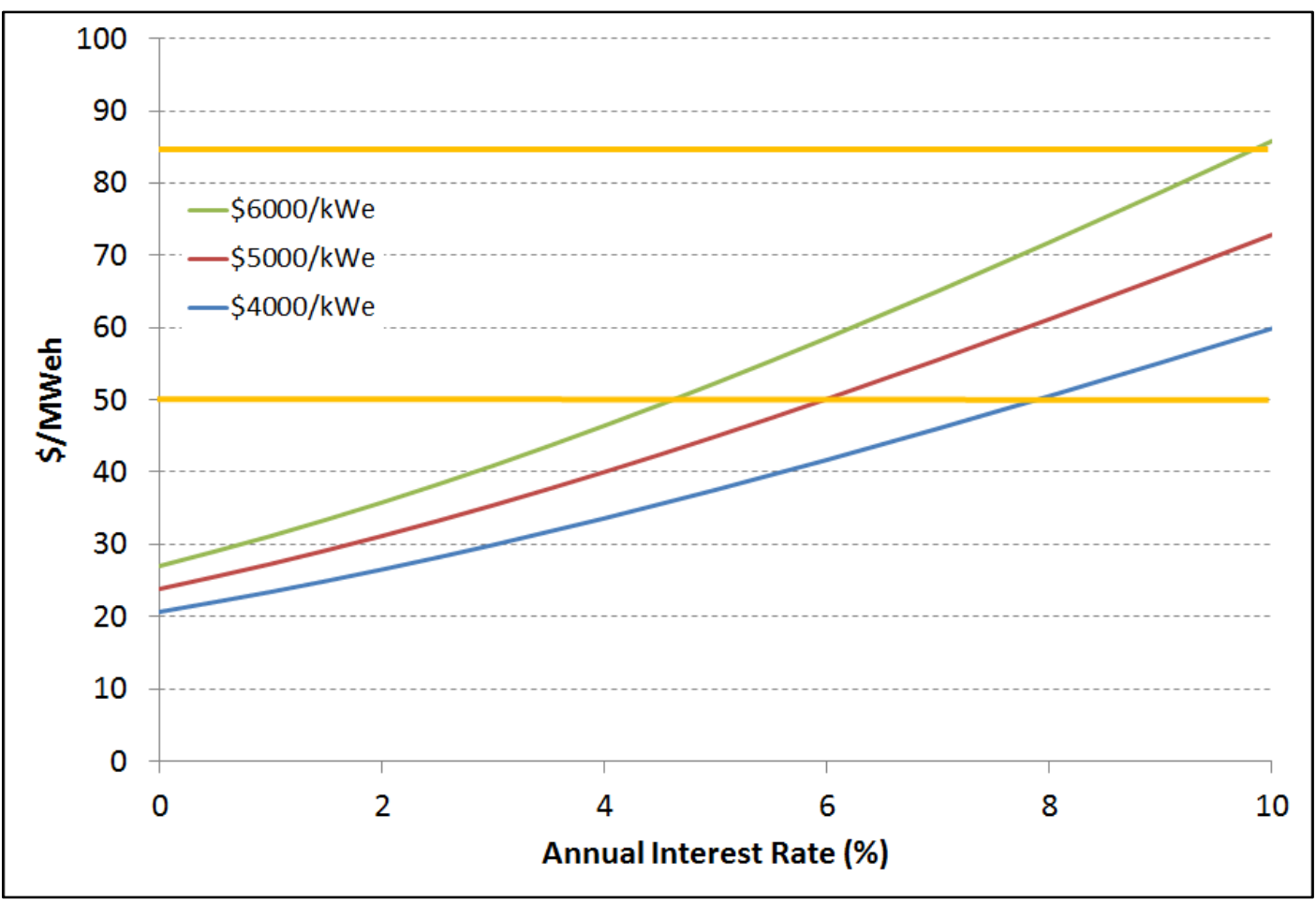

Fig. 14. Total subsidized cost with market shift. 


\section{CONCLUSION AND FUTURE WORK}

Nuclear power can be cost-viable and economically competitive, but the current US market does not support that proposition. However, the market has sufficient future uncertainty, and market externalities (subsidies) have sufficient magnitude to move the overall market so that nuclear power can be more favorable.

Figures 13 and 14 illustrate the complexity of the decision-making process for the power industry in general and the nuclear industry in particular. Figure 1 shows that demand is currently flat, but historically demand has increased at a fairly steady rate. Figure 2 shows that electricity prices are also currently flat, but they also have a historical basis for expected annual increase. Therefore, the power industry should be prepared to build new generation power plants. Based on Fig. 4, however, the wholesale rate can fluctuate by $\$ 30 / \mathrm{MWh}(\mathrm{e})$ in less than a year, meaning that a decision made to move forward now could be economically infeasible before construction starts. This is a scenario the nuclear renaissance suffered in the mid-2000s.

Moving to different power generation sources, Fig. 9 shows that natural gas plants are the lowest cost power generators, meaning they should help maximize profit. However, Fig. 8 shows that gas prices can fluctuate by $\$ 5 / M M B T U$ in less than a year, so a power plant that was profitable six months ago may not be profitable in six months, and vice versa. Installing renewable generation decreases the O\&M and fuel costs, but any government subsidy is subject to legislative approval or disapproval.

The overall attractiveness of the nuclear power industry thus is not solely a function of the capital, O\&M, and fuel costs; it is also a function of the market into which the nuclear power is planned to be sold. As long as markets have inherent uncertainty and as long as the price point for selling the nuclear power is as close to the operating cost as it currently is in some markets, nuclear power will be perceived as a potential investment risk.

Another aspect is the sociopolitical characteristics of the different energy markets. The northeastern states could support a nuclear power plant with the current market without subsidy, but nuclear power does not necessarily enjoy widespread public support in those states. The southeastern states already have relatively low wholesale power prices, and they are also generally supportive of more nuclear construction. For example, Summer, Vogtle, and Watts Bar are all located in the Southeast.

Future work should examine the potential effects on the electricity market from more coal shutdowns in response to Environmental Protection Agency rules, including any carbon limits. Other future work will incorporate nonelectricity markets, including hybrid energy systems. 


\section{REFERENCES}

1. US Energy Information Administration, Electricity Data Browser, http://www.eia.gov/electricity/data/browser/\#/topic/7?agg $=0,1 \&$ geo $=$ vvvvvvvvvvvvo\&endsec $=\mathrm{v}$ g\&freq=M\&start=200101\&end=201402\&ctype=linechart\&ltype=pin\&pin=\&rse=0\&maptype $=0$, accessed October 2, 2014.

2. US Energy Information Administration, "Extended Nuclear Plant Outages Raise Southern California Wholesale Power Prices,” http://www.eia.gov/todayinenergy/detail.cfm?id=10531, accessed October 3, 2014.

3. US Energy Information Administration, "Wholesale Electricity Prices Rose across the United States," http://www.eia.gov/todayinenergy/detail.cfm?id=12211, accessed October 12, 2014.

4. Nuclear Energy Institute, “Costs: Fuel, Operation, Waste Disposal and Life Cycle,” http://www.nei.org/Knowledge-Center/Nuclear-Statistics/Costs-Fuel,-Operation,-WasteDisposal-Life-Cycle, accessed October 12, 2014.

5. CNNUS, "Hot nuclear waste, cold hard cash, and you," http://www.cnn.com/2014/05/16/us/nuclear-waste-money/, accessed October 12, 2014.

6. US Energy Information Administration, Levelized Cost and Levelized Avoided Cost of New Generation Resources in the Annual Energy Outlook, http://www.eia.gov/forecasts/aeo/electricity_generation.cfm, accessed October 12, 2014.

7. US Energy Information Administration, Updated Capital Cost Estimates for Utility Scale Electricity Generating Plants, April 2013.

8. World Nuclear News, Cost of Summer AP1000s Increases, http://www.world-nuclearnews.org/NN-Cost-of-Summer-AP1000s-increases-0310144.html, accessed October 12, 2014.

9. The New York Times, Atomic Power's Green Light or Red Flag, http://www.nytimes.com/2013/06/12/business/energy-environment/nuclear-powers-future-mayhinge-on-georgia-project.html?pagewanted=all\&_r=1\&, accessed October 12, 2014.

10. Dominion, Dominion Shuts Down Kewaunee Power Station Permanently, http://dom.mediaroom.com/2013-05-07-Dominion-Shuts-Down-Kewaunee-Power-StationPermanently, accessed October 12, 2014.

11. Forbes, Loss of Production Tax Credit Brings Big Wind Chill to Cooling Subsidy-Dependent Market, http://www.forbes.com/sites/larrybell/2014/02/09/loss-of-production-tax-credits-bringsbig-wind-chill-to-cooling-subsidy-dependent-market/, accessed October 12, 2014 